\title{
Does Innovation Pay Off in Terms of Firm Performance? - Evidence from the European Automotive Industry -
}

\author{
Philipp Alt ${ }^{1}$
}

\begin{abstract}
Given a more intense competition and substantial investments in research and development $(R \& D)$, this paper investigates the impact of innovation on performance in the European automotive industry. More specifically, using secondary data for 98 observations and running multiple regression models, this study examines the effect of the number of both total and green patent applications, and R\&D intensity on return on assets (ROA). The evidence suggests that both patent applications and R\&D intensity have a positive and significant impact on ROA, whereas green patents are marginally insignificant at the $10 \%$ significance level. The results have important implications for business leaders in the industry indicating that innovation does indeed improve performance.
\end{abstract}

\section{Introduction}

"Innovation distinguishes between a leader and a follower" (Jobs, 2001, as quoted by Griggs (2016)). From a business perspective Steve Jobs, one of the most prominent advocates for innovation in businesses, has highlighted the necessity to innovate for companies in order to stand out from the competition. Similarly, much academic research has emphasized companies' ability to achieve a competitive advantage through innovation (Porter, 1990). With this in mind, automotive manufacturers and suppliers constantly introduce new technologies to the market and modify processes and products. Recent trends such as connected and digital services, autonomous driving or electric mobility drive those dynamic developments. More specifically, the automobile industry is Europe's greatest supporting sector of the R\&D community (investments of $€ 44.7$ billion per year), which demonstrates its important economic position (ACEA, 2017). When assessing the R\&D investment one wonders: Are such large investments justified by the companies' performance and competitive advantage?

Much has been written about the relationship between innovation and business performance, especially in the context of manufacturing or pharmaceuticals (e.g. Roberts, 1999). The literature review suggests that there is consensus among scholars about a positive relationship between both variables. However, existing research fails to account for a lagging effect of innovation measures on performance (e.g. Chun-yao \& Leiyu, 2007), as proposed by Ernst (2001). Furthermore, a very limited number of studies deal with the automotive industry. While Atalay, Anafarta, and Sarvan (2013), for example, examine the effect of innovation on firm performance of Turkish suppliers using surveys, objective measures seem more reliable to draw accurate conclusions. Although the leading car manufacturers and suppliers are among the world's largest investors in $R \& D$ and thus have both unique and interesting characteristics to be examined,

${ }^{1}$ Philipp Alt received a bachelor degree in International Business at Maastricht University in 2017. Currently, he is doing an internship at Porsche Cars North America in the field of Corporate Business Development. Following the internship, Philipp will be continuing his Master studies in International Management / CEMS at Rotterdam School of Management, Erasmus University and National University of Singapore. Contact: philipp.fabian.alt@gmail.com

Innovation and Firm Performance

in the European

Automotive Industry 
surprisingly little empirical research was conducted. Hence, this paper contributes to existing research by testing the above-mentioned relationship and by addressing the shortcomings of existing research, thus filling the gap in literature. More specifically, this paper attempts to investigate what impact innovation has on performance in the European automotive industry ${ }^{2}$. The former represents the independent variable and is measured by the count of both the number of total and green ${ }^{3}$ patent applications and R\&D intensity. The latter denotes the dependent variable, as indicated by Return on Assets (ROA). Additionally, factors explaining the intensity of the association are explained. In more practical words, the question arises whether or not innovative activities pay off in terms of performance. The paper has the following structure. First, a brief introduction into the industry is given. Second, innovation and its distinct types are defined. Third, a review on the existing literature with respect to the aforementioned relationship is provided. Following this, the methodology including the variables is described. Finally, the paper analyses the results of the regression models and discusses the findings before concluding that innovation does indeed pay off while also mentioning some limitations of this research.

\section{The European Automotive Industry}

The automotive industry is an indispensable driver of the European economy. Given the large number of global automotive players and the well-developed infrastructure in the European home market, they accounted for $23 \%$ of the world's motor vehicle production in 2015 - second after China (ACEA, 2016). Out of all that output, the significant majority $(87 \%)$ of vehicles manufactured were passenger cars (ACEA, 2016). While there are almost 300 production and assembly plants in Europe, most of the vehicles are produced in Germany and spread across 42 locations (ACEA, 2016). With respect to innovation, the sector automobiles and parts had the highest number of R\&D investments among European companies in 2016, with Volkswagen AG leading the ranking (European Commission, 2016). Innovative contributions have a multiplier effect on several different economic dimensions. For instance, the European Commission (2017a) states that the automotive industry has an impact on many economic branches such as the steel or information and communication industries. It does not only contribute to four percent of the European Union's Gross Domestic Product (GDP), but also provides for 12 million jobs (European Commission, 2017a).

\section{Literature Review}

Since innovation is a broad and widely-discussed topic, forming the basis for further analysis in this paper, innovation and its different types are to be defined first. The following section then reviews relationship between innovation and performance as proposed by established research and thus, three hypotheses are suggested.

\subsection{Definition of Innovation}

There is a general consensus that innovation denotes newness and firms engage in innovation-seeking activities to strengthen their competitive position (Baregheh, Rowley, \& Sambrook, 2009). For example,

\footnotetext{
${ }^{2}$ Definition: all manufacturers and suppliers are considered European when the country of origin or the headquarter is registered within the European Economic Community in Europe, provided the data is available

${ }^{3}$ In this study, green patents refer to patents that have the Cooperative Patent Classification (CPC) Y02, that is, technologies reducing climate change

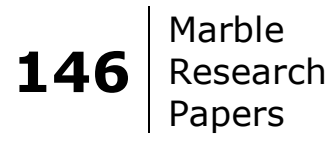


Bessant, Lamming, Noke, and Phillips (2005) define innovation as "the core renewal process in any organisation" (p. 1366). The European Commission (1995) further specifies the idea of novelty by referring to the "successful production, assimilation and exploitation of novelty in the economic and social spheres" (p. 1). Another approach was taken by Jon-Arild, Bjørn, and Lumpkin (2001) who combined previous views on innovation and employed a factor analysis based on multiple industries. They argue that innovation can be referred to as a "single construct, distinguished only by its degree of radicalness" (p. 27).

\subsection{Types of Innovation}

When it comes to different types of innovation, Joseph Schumpeter's contributions to the subject received much attention within the academic community. Schumpeter (1934), as quoted by the OECD (2005, p. 29), referred to the following five categories of innovation: (1) introduction of new products; (2) introduction of new methods of production; (3) opening of new markets; (4) development of new sources of supply for raw materials or other inputs; (5) creation of new market structures in an industry. More recently, Schilling (2017) distinguishes between four types of innovation. First, she points out that product innovations yield new outputs, while process innovations refer to improvements in the methods of production and usually aim at increasing efficiency. Next, radical innovations significantly deviate from existing standards in terms of novelty, whereas incremental innovations are represented by minor modifications to products or processes. Another dimension is classified as competence-enhancing innovation, which refers to companies leveraging prevailing knowledge and resources rather than disregarding previous work products, as in the case of competence-destroying innovations. Finally, Schilling argues that architectural innovations radically impact the system by changing the overall configuration or the relationship between elements that build the system. In contrast, modular innovations primarily adjust the components as such without redesigning the system. This paper bases the analysis on the notion of product and process innovation as well as introduction of new products when referring to innovation. In addition, the models are based on a distinction between innovation input and output, as indicated by R\&D expenditure and patents, respectively (Cloodt $\&$ Hagedoorn, 2003).

\subsection{Innovation and Firm Performance}

Many scholars have examined the relationship between innovation and firm performance, but empirical tests of the concept applied to the European automotive sector are very limited. The following section gives an overview of the review. Generally, the findings appear to be consistent across various industries and geographical regions. For instance, Baldwin and Johnson (1996) compare both the absolute and relative performance between more and less innovative Canadian companies. They find that those focusing on innovation enjoy not only higher sales in absolute numbers but also in terms of a change in the share of outputs and profits relative to the industry, compared to less innovative enterprises. This is supported by Deshpande, Farley, and Websters' (1993) interviews with Japanese vendors and their customers' executives, which suggest that there is a positive relationship between innovativeness in firms and business performance. More precisely, they employ a self-evaluation of profitability, size, market share, and growth rate as performance measure. Regarding Australian firms, Dwyer and Mellor (1993) conclude that those with

Innovation and Firm Performance in the European Automotive Industry 
new product strategies focusing on technical competencies ${ }^{4}$ were most successful with respect new product introductions and profitability. Hall and Bagchi-Sen (2002) confirm the association between innovation and business performance in the Canadian biotech industry by using the relationship between new product introductions and total revenue growth as another proxy.

With respect to other industries, the evidence suggests a positive relationship between innovation and business performance in the manufacturing (Prajogo, 2006), pharmaceutical (Roberts, 1999) or agricultural sector (Diederen, van Meijl, \& Wolters, 2002). More specifically, not only does an elevated level of innovation enable businesses to achieve higher profit rates, it also contributes significantly to the growth rate of production (Diederen et al., 2002). Similar to the agricultural sector, process innovations play an important role in the automobile industry because manufacturing companies strongly depend on efficient methods of production. They conclude that firms with a strong performance are expected to engage in innovative activities and vice versa, that is, innovative companies achieve a better economic performance (Diederen et al., 2002).

As for the Turkish supplier automotive industry, Atalay et al. (2013) investigated the effect of product-, process-, organizational- and marketing innovation on firm performance. They surveyed 113 respondents who rated their firm's capabilities on an innovation and firm performance scale. The findings suggest that there is a positive correlation between both product and process innovation and business performance. However, the authors did not find empirical evidence regarding the effect of marketing and organizational innovation on performance. Although this study investigated automotive suppliers, given the nature of the sample (mostly small and medium-sized enterprises), generalizations to the entire European automotive industry are difficult. Other limitations of existing studies include that the above mentioned examples fail to account for the lagging the effect of innovation on performance. As demonstrated by Ernst (2001), the lagging influence has to be addressed.

Another important stream of innovation literature examines the effect of R\&D input on firm performance. For example, Hsu, Chen, Chen, and Wang (2013) find empirical evidence for a positive effect of both R\&D intensity and total expenditure on net sales, stock returns, but not on operating income, when lagging R\&D expenditure by two years. However, they use the same time lag for all companies in the sample despite investigating nine different industries in the Taiwanese high tech sector. Clearly, there is a different distribution of time lags across sectors. Furthermore, Griliches (1985) confirms the positive relationship by examining the impact of $R \& D$ on both profitability and productivity growth in the American manufacturing industry. Similar results are found in terms of R\&D as indicator of sales growth, while it is claimed that the amount invested needs to surpass a certain benchmark to become effective (Morbey, 1988). More precisely, it is proposed that R\&D intensity improves performance only up to a certain level of investment, while after a particular threshold, decreasing returns are expected (Yeh, Chu, Sher, \& Chiu, 2010). Nevertheless, with respect to a study of the top spending European companies, higher levels of R\&D investments are shown to lead to superior sales growth (Garćia-Manjón \& Romero-Merino, 2012). In conclusion, a meta-analysis

${ }^{4}$ Technical competencies refer to the technical fit, customization and the employment of advanced technologies (Dwyer \& Mellor, 1993)
$148 \mid$\begin{tabular}{l|l} 
Marble \\
Research \\
Papers
\end{tabular} 
generally suggests that R\&D does have a positive effect on financial performance, based on the review of 320 articles (Capon, Farley, \& Hoenig, 1990). Following the evidence from past research, the first hypothesis is predicted.

H1: R\&D intensity has a positive effect on firm performance

One of the very few studies dealing with innovation and performance in the global automotive industry employed a modified production function by using panel data (Chun-yao \& Lei-yu, 2007). More specifically, they incorporated firm profit as output variable and innovation quality, total assets, and number of employees as input variables in their model. Using a random effects model, the researchers find a significant as well as positive association between three proxies of innovation (patent counts, citation-weighted patents, scope of innovations ${ }^{5}$ ) and firm profits. Yet, the panel data set is not suitable to draw conclusions about the link in the more modern European car industry for two reasons. First, while the world's 17 largest automakers covering $91 \%$ of the global production in 2002 are analyzed, only six European manufacturers are included in the sample. The number of observations is not large enough to generalize the findings to the European market. Therefore, this study overcomes this limitation by examining 49 companies in the sector. Additionally, this study retrieves patent data from the EPO instead of the USPTO because European companies are more likely to apply at the home patent office (Ernst, 2001). Second, using a data set from 1983 to 2002 enables Chun-yao and Lei-yu (2007) to investigate the relationship over time, but is too outdated to derive implications for the fast changing and more modern European sector. Hence, this thesis retrieves more recent data to investigate the effect of innovation on performance. In another study, Ernst also provides evidence for a positive relationship between patents and sales (Ernst, 1995, 2001). The second hypothesis is formulated in line with previous findings.

H2: The number of patent applications has a positive effect on firm performance

Given the broad nature of the patent literature, it can be divided into several dimensions such as environmental innovation. The definition of environmental technologies is adopted to define green innovation: "production equipment, [...] procedures, product designs, and product delivery mechanisms that conserve energy and natural resources, [...], and protect the natural environment" (Shrivastava, 1995, p. 185). The explanation is in line with the patent classification that is used to measure green patents in this thesis. Generally, the number of investigations of the impact of environmental innovation on business performance has been increasing. Several researchers confirm a positive relationship between environmental innovation and ROA (e.g. Hart \& Ahuja, 1996; Ngniatedema, Li, \& Illia, 2014; Russo \& Fouts, 1997) or Tobin's q (e.g. King \& Lenox, 2001), especially in the context of manufacturing firms. Similarly, Shrivastava (1995) asserts that cost reductions are a result of lean methods and reduced use of energy.

\footnotetext{
${ }^{5}$ Citation-weighted patents and scope of innovations are defined as "weighing patents by the number of citations a firm i receives relative to all patents in the same industry at time $t$ and average numbers of IPC class (three-digit) into which the USPTO assigns the patents granted to firm i at time t" (Chun-yao \& Lei-yu, 2007, p. 165), respectively. They are sourced from the US Patent and Trademark Office.
} 
More recent research like Zhu and Sarkis (2004) also suggests a positive association between green supply chain management and economic performance in the Chinese manufacturing settings. Using surveys, however, their study fails to incorporate financial or objective measures of performance, but base performance on the respondents' predictions. More specifically, Ghisetti and Rennings (2014) show that energy and resource-efficient innovations have a positive association with pre-tax profits after sales, while the opposite holds true for externality-reducing innovations (e.g. reduced air pollution). The above mentioned studies consider a broad selection of industries. However, it is likely that there are automobile industry-specific effects of environmental innovation. Hence, this study tries to find conclusive results for the sector in question. Following the evidence in the literature, the subsequent hypothesis is constructed.

H3: The number of green patent applications has a positive effect on firm performance

Summarizing, all three hypotheses predict a positive relationship between innovation and performance. This is in line with Baldwin and Johnson (1996) who conclude that "innovation is both a sufficient and a necessary condition for success" (p. 802).

\section{Methodology}

The methodology section is structured as follows. First, the data collection procedure is described. Second, more detailed information on the sample is given. Next, various measures of performance are reviewed before specifically introducing the variables that are relevant in the models of this study in detail. Similarly, the following part discusses several measures of innovation at a broader level before explaining the variables used in this research in more detail.

Figure 1 gives a graphical representation of the variables used in this thesis. Furthermore, all variables satisfy the linear regression assumptions. As mentioned, R\&D investments and patents measure two different dimensions of innovation (input and output). Additionally, incorporating all variables in a combined model does not seem rational given the relatively small sample size. Therefore, the effect of the independent variables on the dependent variable is examined in three separate different models using the ordinary least squares method. The following three main regression models are computed in SPSS:

(1) $R O A_{i, t}=a+b_{1}\left(R D_{-}\right.$intensity $\left.y_{i, t-3}\right)+b_{2}\left(R O A_{i, t-3}\right)+b_{3}$ Dummy $_{2014}+\epsilon$

(2) $R O A_{i, t}=a+b_{1}\left(\ln \left(\right.\right.$ Patents $\left.\left._{i, t-2}+1\right)\right)+b_{2}\left(\ln \left(\right.\right.$ Firm_Size $\left._{i, t-3}\right)+b_{3}\left(R O A_{i, t-3}\right)+b_{4}$ Dummy $_{2014}+\epsilon$

(3) $R O A_{i, t}=a+b_{1}\left(\ln \left(\right.\right.$ Green_Patents $\left.\left._{i, t-2}+1\right)\right)+b_{2}\left(R_{-} O A_{i, t-3}\right)+b_{3}$ Dummy $_{2014}+\epsilon$

, where $i$ represents firm and $t$ year.

$150 \mid$\begin{tabular}{l|l} 
Marble \\
Research \\
Papers
\end{tabular} 


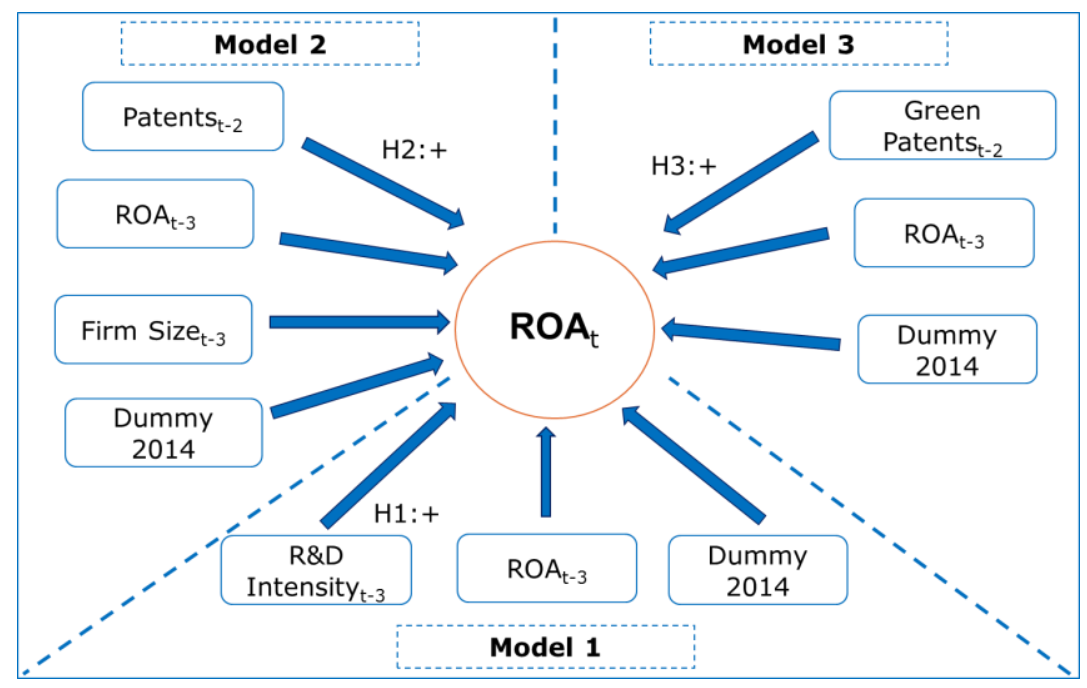

Figure 1: Factors influencing Return on Assets (graphical model)

\subsection{Data Collection}

This study retrieved secondary data from the following four sources: (1) European Patent Office (EPO), (2) ORBIS, (3) the EU Industrial R\&D Investment Scoreboard by the European Commission (which also extracted data from ORBIS) as well as (4) company annual reports. In an attempt to accurately match the names of the company on different databases, an extensive search was conducted to identify all possible names of a company. This is especially the case for the EPO which can provide several different spelling variations, legal names, acronyms for the same company. Since no screening software or algorithm was available for this research, the companies and patents had to be identified and processed manually. Consequently, the original name of the company inserted in the search query has been compared to the PATSTAT standardized names, DOCDB and harmonized names, which are standardized types of names provided by the EPO and OECD ${ }^{6}$. Finally, the type PATSTAT standardized name ${ }^{7}$ is adopted as company identifier to source patent data in this study. In cases where a company was listed with more than a single name, two or three names are used for the same company, and thus, the count of patents was aggregated for each. Also, the NACE Rev. 2 industry classification codes were checked in ORBIS to validate the search results. More specifically, firms with the NACE codes 2910 and 2932 are primarily included in the analysis, which are classified as manufacture of motor vehicles and manufacture of other parts and accessories for motor vehicles, respectively. Other codes such as NACE 2211, indicating the manufacture of rubber tires and tubes, are added in selected cases to encompass companies like Continental or Michelin.

\footnotetext{
${ }^{6}$ Using attributes such as 'applt_seq_nr $>0$ ' in the query reduced the number of search results because human persons with the same name as the company are excluded from the search

7 Psn_name from table tls206_person
} 


\subsection{Sample}

The sample of this study consists of 49 companies in the European automotive industry. Using data for both motor vehicle manufacturers and suppliers in 2011 and 2014 in year $t^{8}$ therefore results in 98 observations ${ }^{9}$. The automotive industry was chosen because of its economic importance in the European economy and because of the innovativeness of global players such as BMW AG. More specifically, the firms selected are part of a R\&D ranking of 1000 top EU companies under the category automobiles \& parts. This ranking is provided annually by the European Commission and referred to as the EU Industrial R\&D Investment Scoreboard. A few additional enterprises such as Audi AG are included in the analysis based on further market research and their important position in the industry. Furthermore, since most of the data is only published for the parent or holding companies, their consolidated group accounts are traced. Whenever those accounts are unavailable, they are substituted by data for subsidiaries. Additionally, joint ventures between one or more companies and other subsidiaries, with a few exceptions, are not introduced as separate entities. In cases of missing values, averages over the longest time frame possible, usually five year averages, are calculated.

\subsection{Measures of Firm Performance}

Firm performance is a multifaceted concept (Murphy, Trailer, \& Hill, 1996) that can be explained by various proxies. Subramanian and Nilakanta (1996) point out that past studies were not able to agree on one measure explaining all dimensions of organizational performance. Venkatraman and Ramanujam (1986) also underline the broad application of the construct by discussing several different spheres of business performance and referring to it as "subset of the overall concept of organizational effectiveness" (p. 803). Furthermore, business performance can be measured by subjective or objective data. The former can include self-indicated judgements on the firm's performance, whereas the latter refers to financial data such as growth in assets (Freel \& Robson, 2004). Dess and Robinsons' (1984) empirical findings suggest that when benchmarking to industry peers, managers' subjective views on their firms' progressive performance like ROA are strongly associated with objective indicators. As part of the objective dimension, a number of researchers use ratios such as return on assets to measure performance (Artz, Norman, Hatfield, \& Cardinal, 2010; Sher \& Yang, 2005; Subramanian \& Nilakanta, 1996; Yun \& Tung-Yu, 2010). Alternative performance indicators include sales as these can account for "direct market feedback, whereas profitability can be substantially influenced by internal company policy" (Ernst, 1995, p. 233). Although Ernst follows a sound argumentation, sales do not seem to account for a more holistic view of performance by, for instance, incorporating both revenues and expenses in the equation. Following this logic, Geroski, Machin, and Van Reenen (1993) employed the operating profit margin as measure of performance in their innovation study.

In this research, $R O A_{t}$ is the dependent variable. In a study of 722 articles in five leading journals, objective accounting measures such as ROA were found to be the most frequently used measure of organizational performance (Richard, Devinney, Yip, \& Johnson, 2009). Even researchers who propose

\footnotetext{
${ }^{8}$ While the year $t$ refers to two observations of the same company in 2011 and 2014 for the dependent variable, the independent variables are lagged and refer to a different year (cf. Section 4.4)

${ }_{9}$ The number of observations varies slightly per variable due to missing values and outliers

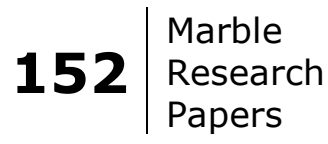


alternative subjective measures of organizational performance like Dess and Robinson (1984), advocate the application of objective measures such as ROA. Motivated by established research, ROA is used and the ratio $\frac{\text { Pre-Tax Operating Income }}{\text { Total Assets }}$ allows for a more accurate comparison between firms of different sizes and organizational structures. Considering that the sample includes firms that operate in various countries implies that different tax schemes apply. Therefore, using pretax metrics makes the data more comparable. Data on the dependent variable is provided by ORBIS and publicly available reports.

$\mathrm{ROA}_{\mathrm{t}-3}$ is one of the independent variables. The same principles of the dependent variable apply to ROAt-3 except that it is lagged by three years compared to ROAt. Based on a simplified application of Granger causality, it is tested if the effect of the other independent variables is caused by ROAt-3. This factor is included in the model to evaluate if performance for the firms at hand has improved or not, given the independent variable. The three-year lag is due to a three-year lag on another independent variable. Additionally, performance in the current period is partially influenced by performance preceding that period (Artz et al., 2010).

\subsection{Measures of Innovation}

Similar to measures of performance, there are several ways of measuring innovation. Some scholars review the use of new product announcements, which are also referred to as "literature-based innovation output indicators (LBIOs)" (Artz et al., 2010; Beneito, 2006, p. 503). Beneito (2006) claims that LBIOs can be found in scientific and technical journals, which allow researchers to classify new product developments by their level of newness. However, he acknowledges that bias and uncertainty in choosing appropriate journals are shortcomings in using LBIOs. Besides, Cloodt and Hagedoorn (2003) make a distinction between a limited and comprehensive scope of innovative performance. While the former refers to new product announcements, the latter covers R\&D and patent activities in addition to commercializing new products in the market (Cloodt \& Hagedoorn, 2003).

An alternative to measuring innovation output is facilitated by Community Innovation Surveys (Eurostat, 2017). They give insights into a large number of different innovation statistics and is a subjective assessment because respondents could be biased or have a poor judgement. Even though the use of patents as measure of innovation has limitations, it is the most widely-used and accepted proxy (Cloodt \& Hagedoorn, 2003). First, the weaknesses of patent counts are outlined before presenting the strengths. For example, Scherer (1965) points out that companies differ in their tendency to patent due to different motivations and due to both firm-specific and industry-specific variations. As this research only investigates one industry, the results do not suffer from the latter limitation. Scherer also draws the attention to discrepancies between the quality of patents, which is supported by Haščič and Migotto (2015). Indeed, a measure showing how high or low the quality of a patent application or granted patent is, is not provided by the EPO. Nevertheless, because the patenting process involves substantial costs, it is likely that patent applications have not only high chances of adoption but also of appropriating economic rents from the invention (Haščič \& Migotto, 2015). This speaks for a higher quality of patents, but the lack of an official indicator of the quality remains. However, more recent research suggests using patent citations to assess their value (Bakker, Verhoeven, Zhang, \& Van Looy, 2016; Yang et al., 2015).

Innovation and Firm Performance

in the European Automotive Industry 
With respect to the advantages of using patent as measure of innovation, Haščič and Migotto (2015) argue that patents can be assessed using objective criteria, are widely available and are an indicator for the output of innovation. Besides, patents are categorized in a specific technological category using the Cooperative Patent Classification (CPC) or International Patent Classification (IPC). This enables a detailed analysis based on the domain of interest such as environmental innovations. Additionally, patents can be considered one of the few indicators that are able to adequately represent transitions to new technologies in a timely manner (Ernst, 1998).

Another measure of innovation represents the monetary amount of R\&D investments. According to Cloodt and Hagedoorn (2003), such R\&D activities are the input in the development process and represent the innovative capabilities of a firm. The authors state that those activities also take past research endeavors into account by building on learning curve effects. Consequently, they claim that the R\&D inputs are essential determinants of subsequent research output and eventually firm performance. This reasoning is applied to this research by incorporating a lagging independent variable. Moreover, when broadening the scope of R\&D expenditures, the number of employees working in the field of R\&D can be taken as indicator of innovative resources (Comanor \& Scherer, 1969). In conclusion, R\&D investments can be considered as input in the innovation process, whereas patents are referred to as output (Cloodt \& Hagedoorn, 2003).

The following variables are used to measure innovation in the models of this study.

1) The variable RD intensity is defined as the ratio of research and development expenditure and additional cash investments over net sales (European Commission, 2016). The R\&D intensity, also known as the R\&D ratio, is a common measure in innovation studies (e.g. Yeh et al., 2010). Data for the R\&D ratio was gathered from the annual EU R\&D scoreboard (European Commission, 2017b) as previously done by GarciaManjón and Romero-Merino (2012), in addition to ORBIS by calculating the figures manually. For companies that had missing values in either data set, the numbers were gathered from the companies' annual reports. Initially, the total R\&D expenditure was used but had to be eliminated due to a highly significant correlation with the control variable, firm size. Therefore, $R \& D$ expenditure was replaced by R\&D intensity owing to the advantage that it is already scaled for firm size. Motivated by past research (e.g. Artz et al., 2010), the same logic of the lagging effect of patents is applied and thus, R\&D intensity is lagged by three years. This study refers to $R \& D$ intensity as input in the innovation process.

2) The variable patent is another explanatory variable measuring innovation. More specifically, the annual number of patent applications with the earliest publication year is counted per firm in the respective years. The earliest publication year is defined as the "year of the earliest publication date of an application, without considering any earlier applications, e.g. of the same patent family" (EPO, 2017a). The publication year is selected instead of, for instance, the application filing year because the former indicates when a patent application is disclosed to the market. This allows to better examine the effect of innovation on firm performance in a competitive environment. In other words, the fact that the competition is able to analyse the patent application and respond to it by developing similar or complementary products, is likely to affect the performance of the applicant.

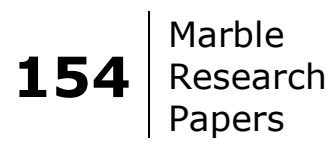


The EPO discloses the number of patent applications. Since the companies in the sample are European, it seems most appropriate to use this database and not, for instance, the United States Patent and Trademark Office's because of home bias. This means that organizations are more likely to apply for a patent in their home market compared to a foreign environment (Ernst, 2001). Additionally, sourcing information from a single patent office such as the EPO makes the applications from various countries and companies more commensurable in terms of equal processing times among entities (Organisation for Economic Co-operation and Development, 2010). Using SQL command language, data can be extracted from the EPO's online database PATSTAT. The database contains detailed information on 100 million patent documents and 90 patent offices worldwide (EPO, 2016).

The variable patent is chosen because it is a widely-used and established measure of innovation in past and present research. Amongst others, Acs and Audretsch (1989) empirically find patents to be a reliable indicator as such. A patent is defined as "document, issued by an authorized governmental agency, granting the right to exclude anyone else from the production or use of a specific new device, apparatus, or process for a stated number of years" (Griliches, 1990, p. 1662). Moreover, using patents as measure of innovation has three main advantages (Haščič \& Migotto, 2015). First, patents can be assessed objectively. Second, patents can be classified into specific technological dimensions. Third, while R\&D intensity is an indicator for the input of innovation, patents measure the output.

Looking at scatterplots and histograms of patents in the dataset at hand reveals that this data shows a skewed distribution, which was already noted by Griliches (1990) and Licht and Zoz (1998). As a result, the variable is transformed by a logarithmic function (specifically, $\ln +1$ because some firms had zero patent applications). After the transformation, the variable patent satisfies all regression assumptions. Furthermore, since patent applications do not have an instant effect on corporate performance, a lagging factor is incorporated to the variable patent (Saunila, Ukko, \& Rantanen, 2014). For example, Ernst (2001) lags the effects of patent applications on sales performance by two to three years after the filing year and finds significant results. Similarly, Artz et al. (2010) finds empirical evidence when lagging the effects of patents on ROA by two years. Therefore, this study takes those results into account and introduces the variable patentst-2. Considering that this study only investigates a single industry ${ }^{10}$ including firms with comparable characteristics, it appears reasonable to assume an equal time lag for all firms between patenting activities and firm performance (Ernst, 2001).

3) Green Patents refer to the number of patent applications with the earliest publication year in the respective year. All patents that have the Cooperative Patent Classification (CPC) Y02 are considered green patents in this study. This class is defined as "technologies or applications for mitigation or adaption against climate change" (EPO \& USPTO, 2017). It is chosen because it covers a relatively broad number of patents in the field of environmental innovation including "climate change mitigation technologies related to transportation [...] and the production and processing of goods" (EPO \& USPTO, 2017). Hence, this class encompasses patents that are also relevant in the automotive setting. The CPC scheme was developed by the EPO and United States Patent and Trademark Office (USPTO) and builds on the IPC classification in more

${ }^{10}$ As mentioned, the automotive industry in question includes both manufacturers and suppliers

Innovation and Firm Performance

in the European

Automotive Industry 
detail. Similar to the variable patents, green patents are transformed by logarithms ( $L N+1)$ and lagged by two years.

\subsection{Control Variables}

A year dummy variable is introduced to control for the year, where $1=2014$ and $0=2011$. To control for firm size, the logarithm of the number of employees is used. Following the logic of the other variables, firm size is lagged by three years. This measure was obtained from the R\&D scoreboard, ORBIS and company reports.

\section{Data Analysis and Results}

To reiterate the purpose of this research, it aims at investigating the effect of two innovation measures, R\&D investments and patents, on firm performance, indicated by ROA. Consequently, three hypotheses are tested in separate regression models, using a $10 \%$ significance level. The section analyzing the results is structure as follows. First, descriptive statistics are reported. Second, the regression outputs are examined.

\subsection{Descriptive Statistics}

In total 98 observations have been collected. Table 1 shows the descriptive statistics before removing outliers and transforming the variables. The skewed distribution of the values is demonstrated by the high standard deviation for the number of total and green patents, the total R\&D expenditure, and firm size (number of employees).

Table 1: Descriptive Statistics (Part 1)

\begin{tabular}{lcccc}
\hline \hline & Minimum & Maximum & Mean & Std. Deviation \\
\hline ROA $t$ & $-7,4$ & 19,1 & 6,2 & 4,9 \\
ROA $A_{t-3}$ & $-7,4$ & 19,1 & 5,3 & 5,6 \\
RD_Expt-3 & 5,2 & 7203,0 & 805,1 & 1396,1 \\
RD_Intensityt-3 &, 0 & 37,5 & 5,2 & 5,7 \\
Green_Patentst-2 & 0 & 1746,0 & 90,2 & 232,4 \\
Patentst-2 &, 0 & 11129,0 & 606,0 & 1568,9 \\
Firm_Sizet-3 & 415,0 & 400070,0 & 56061,6 & 84338,3 \\
\hline
\end{tabular}

Note: This table displays the data before the variables were transformed and observations were excluded due to outliers.

For example, the maximum R\&D expenditure in absolute terms is 7,203 million Euros (Volkswagen), while the mean is 805 million Euros. It is noteworthy that there are companies who have zero patent applications. The fact that the minimum and maximum values are equal for both ROA $A_{t}$ and ROAt-3 was anticipated given that ROA $\mathrm{A}_{\mathrm{t}-3}$ is an independent variable for the observation of ROA $\mathrm{t} 2014$ and ROAt-3 becomes ROA for the observation in 2011. Table 2 displays the descriptive statistics of the transformed variables. Given the

\section{6 \begin{tabular}{l|l} 
Marble \\
Research \\
Papers
\end{tabular}}


skewed distribution and outliers, which are identified by plotting histograms and residuals, outliers for the respective variable were excluded. Thus, the number of observations varies depending on the variable in question. This is no issue in terms of losing degrees of freedom because variables with fewer observations such as patents are not integrated in each model. In addition, RD_Exp is excluded from the model as explained next.

Table 2: Descriptive Statistics (Part 2)

\begin{tabular}{lcccc}
\hline \hline & Minimum & Maximum & Mean & Std. Deviation \\
\hline ROA $t$ & $-7,4$ & 19,1 & 6,2 & 4,9 \\
ROA $A_{\text {-3 }}$ & $-7,4$ & 19,1 & 5,3 & 5,6 \\
RD_Intensityt-3 &, 0 & 10,5 & 4,0 & 2,2 \\
LN_Green_Patentst-2 &, 0 & 7,4 & 2,1 & 2,3 \\
LN_Patentst-2 &, 0 & 9,3 & 4,5 & 2,3 \\
LN__Firm_Sizet-3 & 6,0 & 12,9 & 9,7 & 1,7 \\
\hline
\end{tabular}

Note: This table displays the data after the variables were transformed and observations were excluded due to outliers.

\subsection{Testing the models}

\subsubsection{Model 1 - RD}

Initially, the effect of R\&D expenditure in absolute numbers (and LN) was predicted on ROA, while controlling for firm size. However, the total R\&D figure was dropped due to a highly significant Pearson correlation $(r=.9, p<.01)$ with firm size and thus, concerns for multicollinearity. Instead, data for R\&D intensity is retrieved because it is already scaled for firm size.

With respect to hypothesis $\mathrm{H} 1$, a regression analysis reveals that the R\&D ratio is significant at the $5 \%$ significance level $(p=.026)$ and positively related to ROA, which confirms H1. Given the relatively low number of predictor variables, the adjusted $\mathrm{R}^{2}$ seems high, which is evidence for a good fit of the model. More specifically, the model can explain almost $50 \%$ of the variation in ROA. Furthermore, one unit increase in the R\&D intensity Granger-causes ROA to increase by a considerable amount ( $\beta=.373$ ). With respect to ROA being lagged by three years, it is logical to see a highly significant and positive coefficient considering that ROA in the respective year is influenced by prior performance (Artz et al., 2010). The negative coefficient for the year dummy indicates that ROA is lower in 2014 given the other independent variables ( $\beta$ $=-4.581$ ). Consequently, it appears that the same level of R\&D efforts is less profitable in 2014 than in 2011.

\subsubsection{Model 2 - Patents}


Following the analysis for model 1 , model 2 a provides evidence that patents have a positive and significant effect on ROA. Given the threshold of $10 \%$ significance level set in this study, H2 is accepted at the $10 \%$ alpha level $(p=.094)$. More specifically, due to the nature of the transformed variable, a $1 \%$ increase in patents rises ROA by $0.00403(\beta=.403)$. Even though the adjusted $R^{2}$ is lower than in model $1\left(R^{2}=.346\right)$, it is still much higher than similar studies regressing patent counts on performance in the auto industry (e.g. $\mathrm{R}^{2}=.222$ in Chun-yao and Lei-yu (2007)). The fit measure implies that the model in this thesis can explain $35 \%$ of the variation in ROA. Furthermore, it is noteworthy that firm size carries a negative sign and is not significantly related to ROA, which is also found by Artz et al. (2010) who argue that it can be caused by inefficiencies of larger firms. Given the insignificance of firm size, another regression model (2b) demonstrates that patents are still somewhat marginally significant at the $10 \%$ significance level when dropping firm size $(p=.107)$. In that case, the coefficient of patents decreases $(\beta=.3)$ meaning that a $1 \%$ increase in patents increases ROA by 0.003 given the independent variables. The interpretation of the remaining variables follows the same logic as in model 1 .

\subsubsection{Model 3 - Green Patents}

In the process of building model 3 , green patents were found to be significantly correlated with patents $(r=.884, p<.01)$, non-green patents (computed as the total number of patents minus green patents; $r=.996, p<.01)$ and firm size $(r=.692, p<.01)$. Consequently, to avoid issues with multicollinearity, those variables are dropped from the model and the model only includes three variables, namely green patentst-2, ROA $\mathrm{t}_{-3}$ and Dummy_2014. In contrast to H3, a regression analysis suggests that green patents carry a positive sign, but are not significantly related to ROA at the $10 \%$ significance level $(p=.119)$. Even though the hypothesis can be rejected at the $10 \%$ alpha, the p-value is very close to the cut off value. Additionally, a $1 \%$ increase in green patents rises ROA by $0.00291(\beta=.291)$. Furthermore, the model can explain $28 \%$ of the variation in ROA (adjusted $\mathrm{R}^{2}=.28$ ). Turning to model $3 \mathrm{~b}$, if firm size was included in the model, green patents would be significantly related to ROA $(p=.074)$ and a $1 \%$ increase in green patents rises ROA by $0.00462(\beta=.462)$. However, because the adjusted $R^{2}\left(R^{2}=.28\right)$ did not improve compared to model $3 a$ and due to collinearity between green patents and firm size, the model without firm size is interpreted in the discussion.

\section{Discussion}

The purpose of this study is to investigate the effect of innovation on performance by taking the number of patent applications (total and green) and R\&D investments as proxy for the former and ROA as indicator for the latter. The results are consistent with hypotheses 1 and 2 but fail to support hypothesis 3 . Applying the resource-based framework (Barney, 1991) to the automotive industry can explain one of the reasons why there is evidence of a positive relationship between the R\&D intensity and performance. Assuming that the higher the proportion of sales reinvested in R\&D activities, the higher the number of research projects. This implies a greater exposure to challenges, while solving those by interacting with a larger number of stakeholders such as customers or suppliers. As a result of a greater knowledge-sharing, extended network and more intense relationship building, the companies are able to benefit for two reasons (Schilling, 2017). First, those further developed resources can be considered "socially complex" (Barney, 1991, p. 110) and depend on the firm's unique history and thus, are difficult for competitors to imitate. Second, learning curve

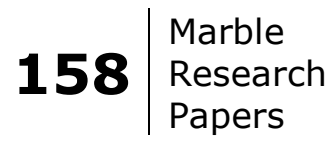


effects are created, which translates into increasing returns through gains in, for instance, efficiency (Cloodt \& Hagedoorn, 2003). Hall, Griliches, and Hausman (1986, p. 265) support this argumentation by stating: "annual research and development expenditures of a firm are considered to be investments which add to a firm's stock of knowledge." Combining those points shows that firms can enjoy a competitive advantage through R\&D investment activities and the introduction of new products.

Moreover, automotive manufacturers' and suppliers' core competencies are considered to be technology developments such as engines. For example, the European Commission (2016b) suggests that almost $80 \%$ of the total R\&D investments are dedicated to this field of research in the automobiles and parts sector. This is in line with the findings of this study showing that companies are most profitable when they invest their $R \& D$ capital in their core competencies. Moreover, the strong effect of R\&D investments on performance shows why the vehicle companies heavily invest in research. For instance, the European Commission (2016a) demonstrates that the European automotive industry has a R\&D intensity ratio of $5.4 \%$, which is much higher compared to the American or Japanese counterparts (European Commission, 2016). Nevertheless, given that the R\&D intensity is significant at the $5 \%$ level $(p=.026)$ and not at $1 \%$ or less, could suggest that some of the motor companies actually overinvest and returns diminish when a certain level of investment is surpassed (Yeh et al., 2010).

As predicted, patents are found to be positively related to performance. The vehicle manufacturers and suppliers already know the value of the technology by the time they apply for and publish the patent through the EPO. Provided the time lag holds and the applications are granted, new product developments or new components are soon to be launched in the market. Given the protection and a first-mover advantage, innovative companies are thus able to capture (temporary) monopoly rents, especially in the case of radical innovations. Those innovations include advances in the field of battery technologies. The companies are then able to charge a premium price for their innovations, which increases their performance. Moreover, patents give companies an additional revenue stream through licensing. While this study examines patent applications, due to the high number of granted patent applications at the EPO (e.g. 64\% 11 in 2012) and the high quality of applications at the EPO (Ernst, 2001), this implies the following: the higher the number of submissions, the higher the probability of extra cash flows. Even though it might appear that partially opening up the technology could give the competitor an advantage, Hsu et al. (2013) assert that licensing patents does not improve the licensees' research capabilities as such. Instead, relying on internal resources leads to the most effective improvements in one's competences.

However, the evidence with respect to patents is not as strong as expected $(p=.094)$. There are at least three plausible reasons. First, even though patent applications at the EPO have a higher chance of commercial success due to a superior quality of the technology applied for than at national patent offices, they come along with higher costs (Ernst, 2001). Additionally, increasing the number of applications raises coordination and administrative costs such as consultations with lawyers. The relatively weak evidence of the effect of patents on ROA can therefore be attributed to higher transaction costs, which decrease

\footnotetext{
11 The number is calculated by dividing the total number of patents granted by the total number of applications in the field "transport" (EPO, 2017b)
} 
operating income (nominator of ROA). Second, patenting might not be the most effective instrument to protect innovations in the automotive sector. For example, Brouwer and Kleinknecht (1999) found that patent protection for product innovations are only regarded as modestly important by the majority of respondents in this sector. While their study uses outdated data, it is even more likely that motor vehicle companies apply a partially open innovation strategy by collaborating with external developers (Schilling, 2017). For example, innovations of digital products like connected car systems benefit from a protection strategy other than patents to a certain degree. However, the core software codes are certainly kept inhouse. This implies that defence mechanisms other than patents are used for some product categories and thus, the effect of patents on performance is weakened. Third, following the notion of patent as protection scheme, it can be argued that automotive companies are not exclusively motivated to patent in order to secure their innovations and improve their performance. Instead, patent applications are a tool to limit or prevent competitors' patent opportunities by covering various technological fields that are close to the contenders' areas of expertise (Artz et al., 2010). As a result, this patent strategy does not contribute to a higher performance per se.

As for green patents, some of the above-mentioned explanations for patents are also valid. Nevertheless, there are more arguments that are especially relevant for green patents. Although the results differ to some extent from other studies investigating manufacturing firms, industry-wide differences are acknowledged (Hart \& Ahuja, 1996; Ngniatedema et al., 2014). Based on the evidence of this study and in comparison to other studies, it can be concluded that environmental innovations have unique effects on performance in the automotive industry. The relatively weak impact could be attributed to the structure of the industry where several large players such as Daimler or BMW compete at a similar high level and investments in green innovation do not lead to a significantly superior performance. Under the assumption that many firms mention some of their environmental innovations in sustainability reports, consumers are made aware of such green practices. While Russo and Fouts (1997) argue that those firms are able to increase their (brand) reputation and thus sales when engaging in environmentally-friendly activities, the improved perception primarily applies to environmentally-conscious consumers. The broader customer segment of the car industry, however, has a critical view on the companies' sustainability approaches, which can also be linked to the concept of greenwashing (Bowen \& Aragon-Correa, 2014). More specifically, many customers believe that the companies engage in green or socially-accepted practices to look good in the eyes of both consumers and investors rather than for the sake of mitigating climate change. Consequently, green patents do not necessarily increase sales and thus, ROA.

The finding that green innovation does not significantly lead to higher ROA is also supported by a practical perspective. For example, McKinsey \& Company (2013) argues that the marginal costs of investing in green technologies such as electric mobility increase strongly. They support their quantitative findings by stating that changes that are effortlessly implemented are already put in place and the next wave of innovations is more costly. This rather implies that green innovations reduce ROA to some extent. Moreover, due to higher development costs of green innovative products such as hybrid or electric cars, the price is much higher than conventional types of engines, which decreases the demand for sales and hence, ROA. Additionally, linking the methodology to the findings can explain the moderately weak evidence. More specifically, given the investigation of one type of green patent classification, it is not surprising that not all

$160 \mid$\begin{tabular}{l|l} 
Marble \\
Research \\
Papers
\end{tabular} 
companies engage in this particular field of innovation and the fairly small sample size might not be large enough to explain the variation in ROA.

\section{Conclusion}

This thesis has examined the effects of innovation on firm performance in the European automotive industry. While previous research generally finds a positive relationship between innovation and firm performance, this theory is not sufficiently tested yet with respect to the automotive industry with its substantial R\&D investments and important position in the economy. Furthermore, existing studies fail to account for the lagging effect of innovation measures on performance. Therefore, this paper has investigated the effect of innovation on firm performance in the European automotive industry and provided explanations by addressing existing gaps in the literature. Since those innovation measures represent different dimensions of innovation (that is, input and output), several regression models show the following results. In line with previous research, the evidence of this study suggests a positive and significant impact of both R\&D intensity and patents on ROA at the $10 \%$ significance level. The performance advantage can be primarily explained by the resource-based framework given that more frequent interactions in R\&D projects result in difficult to imitate capabilities. Other reasons include learning-curve effects and the ability to capture monopoly rents to a certain extent. The relatively weak effect of patents on ROA can be attributed to applicants' motivations to patent in order to limit competitors' patenting opportunities, in addition to increased transaction costs in the patenting process. In contrast to past research, this thesis does not find empirical support for a positive effect of green patents on performance at the $10 \%$ significance level. Reasons for this evidence include customers' critical view questioning genuine motivation of the company to reduce the environmental impact without aiming for enhanced performance in the first place. It is also suggested that the positive effect is weakened by increasing marginal costs of green innovations.

Applying the results to the business world has important implications. Concretely, it seems to be of great importance for managers in the industry to know that, indeed, R\&D efforts improve the performance. However, the current study was limited by, amongst others, the small sample size. This was due to the reliance on publicly available reports and data. Because data on R\&D expenditure was not available for each company in the sector or in some cases only for the parent company, averages of the existing years were adopted. Therefore, the number of variables to be included in the regression models was limited. Moreover, the number of years the variables were lagged by, is based on past research. However, the models do not specifically test for the significance of the effect of several time lags using the data set at hand. Another major limitation is that quality differences of patent applications are not taken into account. Since the picture of innovation and performance in the car industry is still incomplete, future research is strongly suggested. For example, value-adding future contributions could include the following: (1) increasing the sample size and time period, (2) substituting for another proxy of performance and innovation (e.g. the number of successful new product introductions or patent citations), (3) investigating other patent classifications in the field of electric cars and (4) testing the effects based on a more extended test of Granger causality.

\section{References}

Innovation and Firm Performance

in the European

Automotive Industry 
ACEA. (2016). The Automobile Industry Pocket Guide 2016/2017. Retrieved from http://www.acea.be/uploads/publications/ACEA_Pocket_Guide_2016_2017.pdf

ACEA. (2017). ACEA Economic and Market Report: Quarter 42016 Retrieved from http://www.acea.be/uploads/statistic_documents/Economic_and_Market_Report_Q4_2016.pdf

Acs, Z., \& Audretsch, D. B. (1989). Patents as a Measure of Innovative Activity. Kyklos, 42(2), 171-180.

Artz, K. W., Norman, P. M., Hatfield, D. E., \& Cardinal, L. B. (2010). A Longitudinal Study of the Impact of R\&D, Patents, and Product Innovation on Firm Performance. Journal of Product Innovation Management, 27(5), 725-740. doi:10.1111/j.1540-5885.2010.00747.x

Atalay, M., Anafarta, N., \& Sarvan, F. (2013). The Relationship between Innovation and Firm Performance: An Empirical Evidence from Turkish Automotive Supplier Industry. Procedia - Social and Behavioral Sciences, 75, 226-235.

Bakker, J., Verhoeven, D., Zhang, L., \& Van Looy, B. (2016). Patent citation indicators: One size fits all? Scientometrics, 106(1), 187-211. doi:10.1007/s11192-015-1786-0

Baldwin, J. R., \& Johnson, J. (1996). Business strategies in more- and less-innovative firms in Canada. Research Policy, 25(5), 785-804. doi:http://dx.doi.org/10.1016/0048-7333(95)00875-6

Baregheh, A., Rowley, J., \& Sambrook, S. (2009). Towards a multidisciplinary definition of innovation. Management Decision, 47(8), 1323-1339. doi:doi:10.1108/00251740910984578

Barney, J. (1991). Firm Resources and Sustained Competitive Advantage. Journal of Management, 17(1), 99-120. doi:doi: $10.1177 / 014920639101700108$

Beneito, P. (2006). The innovative performance of in-house and contracted R\&D in terms of patents and utility models. Research Policy, 35(4), 502-517.

Bessant, J., Lamming, R., Noke, H., \& Phillips, W. (2005). Managing innovation beyond the steady state. Technovation, 25(12), 1366-1376. doi:http://doi.org/10.1016/j.technovation.2005.04.007

Bowen, F., \& Aragon-Correa, J. A. (2014). Greenwashing in Corporate Environmentalism Research and Practice. Organization \& Environment, 27(2), 107-112. doi:doi:10.1177/1086026614537078

Brouwer, E., \& Kleinknecht, A. (1999). Innovative output, and a firm's propensity to patent. Research Policy, 28(6), 615-624. doi:http://dx.doi.org/10.1016/S0048-7333(99)00003-7

Capon, N., Farley, J. U., \& Hoenig, S. (1990). Determinants of Financial Performance: A Meta-Analysis. Management Science, 36(10), 1143-1159. Retrieved from

Chun-yao, T., \& Lei-yu, W. (2007). Innovation quality in the automobile industry: measurement indicators and performance implications. International Journal of Technology Management, 37(1/2).

Cloodt, M. M. A. H., \& Hagedoorn, J. (2003). Measuring innovative performance: is there an advantage in using multiple indicators? , Retrieved from WorldCat.org database.

Comanor, W. S., \& Scherer, F. M. (1969). Patent Statistics as a Measure of Technical Change. Journal of Political Economy, 77(3), 392-398.

Deshpande, R., Farley, J. U., \& Webster, Jr. (1993). Corporate Culture, Customer Orientation, and Innovativeness in Japanese Firms: A Quadrad Analysis / Rohit Deshpande, John U. Farley, Jr. Webster. Journal of marketing, 57(1), 23.

Dess, G. G., \& Robinson, R. B. (1984). Measuring Organizational Performance in the Absence of Objective Measures: The Case of the Privately-Held Firm and Conglomerate Business Unit. Strategic Management Journal, 5(3), 265-273.

$162 \mid$\begin{tabular}{l|l} 
Marble \\
Research \\
Papers
\end{tabular} 
Diederen, P., van Meijl, H., \& Wolters, A. (2002). Innovation and Farm Performance: The Case of Dutch Agriculture. In A. Kleinknecht \& P. Mohnen (Eds.), Innovation and Firm Performance (pp. 73-85). Hampshire and New York: Palgrave.

Dwyer, L., \& Mellor, R. (1993). Product Innovation Strategies and Performance of Australian Firms. Australian Journal of Management (University of New South Wales), 18(2), 159.

EPO. (2016). The PATSTAT product line - Discover the fascination of patent data. Retrieved from http://documents.epo.org/projects/babylon/eponet.nsf/0/D2445C1BDDF9A1D3C1258056004915E9/ \$File/PATSTAT_product_line_en.pdf

EPO. (2017a). Patent infromation services for experts. PATSTAT Online 2017 Spring Edition, from European Patent Office https://data.epo.org/expert-services/index-2-3-4.html

EPO. (2017b). Statistics. Retrieved from https://www.epo.org/about-us/annual-reportsstatistics/statistics.html\#granted

EPO, \& USPTO. (2017). CPC scheme and CPC definitions. Retrieved from http://www.cooperativepatentclassification.org/cpcSchemeAndDefinitions/table.html.

Ernst, H. (1995). Patenting strategies in the German mechanical engineering industry and their relationship to company performance. Technovation, 15(4), 225-240. doi:http://dx.doi.org/10.1016/01664972(95)96605-S

Ernst, H. (1998). Patent portfolios for strategic R\&D planning. Journal of Engineering and Technology Management, 15(4), 279-308. doi:http://dx.doi.org/10.1016/S0923-4748(98)00018-6

Ernst, H. (2001). Patent applications and subsequent changes of performance: evidence from time-series cross-section analyses on the firm level. Research Policy, 30(1), 143-157.

European Commission. (1995). Green Paper on Innovation. Retrieved from http://europa.eu/documents/comm/green_papers/pdf/com95_688_en.pdf

European Commission. (2016). The 2016 EU Industrial R\&D Investment Scoreboard EU. Retrieved from http://iri.jrc.ec.europa.eu/scoreboard16.html

European Commission. (2017a). Automotive Industry. Retrieved from https://ec.europa.eu/growth/sectors/automotive_en

European Commission. (2017b). The EU Industrial R\&D Investment Scoreboard. Retrieved from http://iri.jrc.ec.europa.eu/scoreboard.html

Eurostat. (2017). COMMUNITY INNOVATION SURVEY (CIS). Retrieved from http://ec.europa.eu/eurostat/web/microdata/community-innovation-survey

Freel, M. S., \& Robson, P. J. A. (2004). Small Firm Innovation, Growth and Performance. International Small Business Journal, 22(6), 561-575. doi:doi:10.1177/0266242604047410

Garćia-Manjón, J. V., \& Romero-Merino, M. E. (2012). Research, development, and firm growth. Empirical evidence from European top R\&D spending firms. Research Policy, 41(6), 1084-1092.

Geroski, P., Machin, S., \& Van Reenen, J. (1993). The Profitability of Innovating Firms. The RAND Journal of Economics, 24(2), 198-211.

Ghisetti, C., \& Rennings, K. (2014). Environmental innovations and profitability: How does it pay to be green? An empirical analysis on the German innovation survey. Journal of Cleaner Production, 75 , 106-117.

Griggs, B. (2016). 10 great quotes from Steve Jobs. CNN Retrieved from

Innovation and Firm Performance in the European Automotive Industry 
http://edition.cnn.com/2012/10/04/tech/innovation/steve-jobs-quotes/

Griliches, Z. (1985). Productivity, R\&D, and basic research at the firm level in the 1970s: National Bureau of Economic Research Cambridge, Mass., USA.

Griliches, Z. (1990). Patent Statistics as Economic Indicators: A Survey. Journal of Economic Literature, 28(4), 1661-1707.

Hall, B., Griliches, Z., \& Hausman, J. A. (1986). Patents and R and D: Is There a Lag? International Economic Review, 27(2), 265-283.

Hall, L., \& Bagchi-Sen, S. (2002). A study of R\&D, innovation, and business performance in the Canadian biotechnology industry. Technovation, 22(4), 231-244.

Hart, S. L., \& Ahuja, G. (1996). DOES IT PAY TO BE GREEN? AN EMPIRICAL EXAMINATION OF THE RELATIONSHIP BETWEEN EMISSION REDUCTION AND FIRM PERFORMANCE. Business Strategy and the Environment, 5(1), 30-37.

Haščič, I., \& Migotto, M. (2015). Measuring environmental innovation using patent data. ECD Environment Working Papers, 89 . Retrieved from http://dx.doi.org/10.1787/5js009kf48xw-en

Hsu, F.-J., Chen, M.-Y., Chen, Y.-C., \& Wang, W.-C. (2013). An empirical study on the relationship between R\&D and financial performance. Journal of Applied Finance and Banking, 3(5), 107.

Jon-Arild, J., Bjørn, O., \& Lumpkin, G. T. (2001). Innovation as newness: what is new, how new, and new to whom? European Journal of Innovation Management, 4(1), 20-31.

King, A., \& Lenox, M. (2001). Does It Really Pay to Be Green?: An Empirical Study of Firm Environmental and Financial Performance. Journal of Industrial Ecology, 5(1), 105-116.

Licht, G., \& Zoz, K. (1998). Patents and R\&D an Econometric Investigation Using Applications for German, European and US Patents by German Companies. Annales d'Economie et de Statistique(49/50), 329-360.

McKinsey \& Company. (2013). The road to 2020 and beyond: What's driving the global automotive industry? Retrieved from http://www.mckinsey.com/industries/automotive-and-assembly/our-insights/theroad-to-2020-and-beyond-whats-driving-the-global-automotive-industry

Morbey, G. K. (1988). R\&D: Its relationship to company performance. The Journal of Product Innovation Management, 5(3), 191-200.

Murphy, G. B., Trailer, J. W., \& Hill, R. C. (1996). Measuring performance in entrepreneurship research. Journal of Business Research, 36(1), 15-23. doi:http://dx.doi.org/10.1016/0148-2963(95)00159-X

Ngniatedema, T., Li, S., \& Illia, A. (2014). Understanding the Impact of Green Operations on Organizational Financial Performance: An Industry Perspective. Environmental Quality Management, 24(1), 45-59.

OECD. (2005). Oslo Manual, GUIDELINES FOR COLLECTING AND INTERPRETING INNOVATION DATA. Retrieved from http://www.oecdilibrary.org/docserver/download/9205111e.pdf?expires=1492423252\&id=id\&accname=guest\&check sum =0BFAEDBB0459E280CC8E988C509310C9

Organisation for Economic Co-operation and Development. (2010). Measuring innovation : a new perspective OECD innovation strategy; OECD innovation strategy., Retrieved from http://www.oecdilibrary.org/docserver/download/9210041e.pdf?expires=1498563076\&id=id\&accname=ocid177396\& checksum $=24538$ EF8613E178794E4C790F31DC577

\section{$164 \mid$\begin{tabular}{l|l} 
Marble \\
Research
\end{tabular} Papers}


Porter, M. E. (1990). The competitive advantage of nations: New York: Free Press.

Prajogo, D. I. (2006). The relationship between innovation and business performance-a comparative study between manufacturing and service firms. Knowledge and Process Management, 13(3), 218-225.

Richard, P. J., Devinney, T. M., Yip, G. S., \& Johnson, G. (2009). Measuring Organizational Performance: Towards Methodological Best Practice. Journal of Management, 35(3), 718-804. doi:doi: $10.1177 / 0149206308330560$

Roberts, P. W. (1999). Product innovation, product-market competition and persistent profitability in the U.S. pharmaceutical industry. Strategic Management Journal, 20(7), 655-670.

Russo, M. V., \& Fouts, P. A. (1997). A resource-based perspective on corporate environmental performance and profitability. Academy of Management Journal, 40(3), 534-559.

Saunila, M., Ukko, J., \& Rantanen, H. (2014). Does Innovation Capability Really Matter for the Profitability of SMEs? Knowledge and Process Management, 21(2), 134-142.

Scherer, F. M. (1965). Firm Size, Market Structure, Opportunity, and the Output of Patented Inventions. The American Economic Review, 55(5), 1097-1125.

Schilling, M. A. (2017). Strategic Management of Technological Innovation (Fifth Edition ed.). 2 Penn Plaza, New York, NY McGraw-Hill Education.

Sher, P. J., \& Yang, P. Y. (2005). The effects of innovative capabilities and R\&D clustering on firm performance: the evidence of Taiwan's semiconductor industry. Technovation, 25(1), 33-43.

Shrivastava, P. (1995). Environmental Technologies and Competitive Advantage. Strategic Management Journal, 16, 183-200.

Subramanian, A., \& Nilakanta, S. (1996). Organizational innovativeness: Exploring the relationship between organizational determinants of innovation, types of innovations, and measures of organizational performance. Omega, 24(6), 631-647. doi:http://dx.doi.org/10.1016/S0305-0483(96)00031-X

Venkatraman, N., \& Ramanujam, V. (1986). Measurement of Business Performance in Strategy Research: A Comparison of Approaches. The Academy of Management Review, 11(4), 801-814.

Yang, G.-C., Li, G., Li, C.-Y., Zhao, Y.-H., Zhang, J., Liu, T., . . Huang, M.-H. (2015). Using the comprehensive patent citation network (CPC) to evaluate patent value. Scientometrics, 105(3), 1319-1346. doi:10.1007/s11192-015-1763-7

Yeh, M.-L., Chu, H.-P., Sher, P. J., \& Chiu, Y.-C. (2010). R\&D intensity, firm performance and the identification of the threshold: fresh evidence from the panel threshold regression model. Applied Economics, 42(3), 389-401. doi:10.1080/00036840701604487

Yun, K., \& Tung-Yu, T. (2010). FROM SUCCESSFUL INNOVATION TO MARKET PROFITABILITY. International Journal of Organizational Innovation, 3(2).

Zhu, Q., \& Sarkis, J. (2004). Relationships between operational practices and performance among early adopters of green supply chain management practices in Chinese manufacturing enterprises. Journal of Operations Management, 22(3), 265-289. doi:http://dx.doi.org/10.1016/j.jom.2004.01.005 